\section{TESTING OF CORRELATION BETWEEN AMOUNTS OF VISCERAL AND SUBCUTANEOUS ABDOMINAL ADIPOSE TISSUE IN OBESE PEOPLE MEASURED BY ULTRASOUND AND BIOCHEMICAL INDICATORS OF GLYCOLIPID STATUS}

\author{
ISPITIVANJE POVEZANOSTI KOLIČINE VISCERALNOG \\ I SUPKUTANOG ABDOMINALNOG MASNOG TKIVA \\ GOJAZNIH OSOBA MERENIH ULTRAZVUKOM I \\ BIOHEMIJSKIH POKAZATELJA GLIKOLIPIDNOG STATUSA
}

${ }^{1}$ Univerzitet u Beogradu, Medicinski fakultet, Srbija

${ }^{2}$ Centar za radiologiju i magnetnu rezonancu, Klinički centar Srbije, Beograd, Srbija

Correspondence: jovanovicdrluka@gmail.com

\title{
Abstract
}

Introduction: Obesity is a growing health problem in economically developed countries. Abdominal fat is distributed in two large compartments: visceral fat is localized in the abdominal cavity (around the abdominal organs) and subcutaneous fat (between the skin and muscle layers of the abdominal wall). Ultrasonography is the most appropriate imaging method for estimating the amount of visceral and subcutaneous abdominal fat in obese patients.

Aim: The aim is to assess the correlation between the amount of visceral and subcutaneous abdominal adipose tissue, estimated by ultrasound in obese individuals, and biochemical indicators of their glycolipid status.

Material and Methods: Retrospective study included 183 adult obese patients (131 women and 52 men, mean age $42.6 \pm 12.2$, mean weight $123.4 \pm 26.7 \mathrm{~kg}$, mean BMI $\left.43.5 \pm 7.6 \mathrm{~kg} / \mathrm{m}^{2}\right)$, in whom diameters of visceral (dVAFT) and subcutaneous abdominal fat (dSCAFT) were measured by ultrasonography. Following anthropometric parameters, height, weight, waist circumference (WC) and hip cimrcumference (HC) were also measured. Also, biochemical analysis of the concentration of glucose, insulin, $\mathrm{HbAlc}$, triglycerides and cholesterol (parameters of the glycolipid status) was done. Correlation among these parameters was tested using Pearson's test of linear correlation ( $\mathrm{r}$ ).

Results: Positive correlation was found between the dVAFT and all analyzed biochemical parameters of the glycolipid status $(\mathrm{p}<0.001)$. The exceptions were total cholesterol $(\mathrm{p}=0.158)$, negative correlation between the dSCAFT and concentrations of serum glucose, HbAlc and triglycerides $(\mathrm{p}<0.01)$, dVAFT/dSCAFT index most strongly positively correlated with the glucose concentration $(r=0.534)$, HbAlc $(r=0.456)$ and triglyceride levels $(r=0.443)$. WC and $\mathrm{WC} / \mathrm{HC}$ index significantly correlated with the concentration of all biochemical parameters of glycolipid status, except total cholesterol, but less strongly than dVAFT and dVAFT/

Keywords:

Obesity,

Ultrasonography,

Glycolipid status
dSCAFT index.

Conclusion: Visceral and subcutaneous abdominal fat diameters were measured by ultrasound, and especially dVAFT/dSCAFT index, express stronger correlation with the biochemical parameters of glycolipid status, than the anthropometric parameters, in adult obese people.
Jovanović L. et al. MedPodml 2017, 68(2):26-32

(c)

The authors declare no conflicts of interest. doi: $10.5937 / \mathrm{mp} 68-13436$

Editorial board: podmladak.med.bg@gmail.com 
Jovanović et al. Testing of correlation between amounts of visceral and subcutaneous abdominal adipose tissue in obese people measured by ultrasound and biochemical indicators of glycolipid status. MedPodml 2017, 68(2):26-32

\section{Sažetak}

Uvod: Gojaznost je rastući zdravstveni problem u većini ekonomski razvijenih zemalja. Abdominalno masno tkivo je raspoređeno u dva velika odeljka: visceralno je lokalizovano u trbušnoj duplji, oko abdominalnih organa, a supkutano između kože i mišićnog sloja abdominalnog zida. Ultrasonografija je najpogodnija vizualizaciona metoda za procenu količine visceralnog i supkutanog odeljka abdominalnog masnog tkiva u gojaznih osoba. Cilj: Ispitivanje povezanosti količine visceralnog i supkutanog abdominalnog masnog tkiva, merenih ultrazvukom kod gojaznih osoba i biohemijskih pokazatelja glikolipidnog statusa.

Materijal i Metode: U retrospektivnu studiju je uključeno 183 odraslih gojaznih pacijenata (131 žena i 52 muškarca, prosečne starosti 42,6 \pm 12,2 godina, prosečne težine 123,4 $\pm 26,7 \mathrm{~kg}$, prosečnog BMI 43,5 $\pm 7,6 \mathrm{~kg} / \mathrm{m}^{2}$ ), kojima su rađeni ultrasonografsko merenje prečnika visceralnog (dVAMT) i supkutanog (dSCAMT) abdominalnog masnog tkiva, merenje antropometrijskih parametara: visine, težine, obima struka (OS) i obima kukova $(\mathrm{OK})$, kao i biohemijske analize koncentracije glukoze, insulina, glikoliziranog hemoglobina (HbA1c), triglicerida i holesterola (parametri glikolipidnog statusa), čija je povezanost testirana Pirsonovim testom linearne korelacije (r).

Rezultati: Utvrđena je pozitivna korelacija između dVAMT i svih analiziranih biohemijskih parametara glikolipidnog statusa $(\mathrm{p}<0,001)$, osim ukupnog holesterola $(\mathrm{p}=0,158)$, kao i negativna korelacija između dSCAMT i koncentracije serumske glukoze, HbA1c i triglicerida $(\mathrm{p}<0,01)$. Indeks dVAMT/dSCAMT je najviše pozitivno korelirao $(\mathrm{p}<0,001)$ sa koncentracijom glukoze $(r=0,534), \operatorname{HbA1c}(r=0,456)$ i triglicerida $(r=0,443)$. Obim struka i indeks OS/OK su statistički značajno korelirali sa koncentracijom svih biohemijskih parametara glikolipidnog statusa, osim ukupnog holesterola, mada slabije nego dVMAT i indeks dVAMT/dSCAMT. Prečnik visceralnog abdominalnog masnog tkiva je najviše korelirao sa obimom struka, dSCAMT sa obimom kukova, a indeks dVAMT/ dSCAMT sa indeksom OS/OK.

Ključne reči: ultrazvuk, gojaznost, glikolipidni status
Zaključak: Prečnici visceralnog i supkutanog masnog tkiva u odraslih gojaznih osoba, mereni ultrazvukom, a posebno njihov međusobni odnos, pokazuju bolju korelaciju sa biohemijskim parametrima glikolipidnog statusa nego antropometrijski parametri.

\section{Uvod}

Gojaznost je rastući zdravstveni problem u većini ekonomski razvijenih zemalja, tako da sada taj problem treba tretirati kao hroničnu bolest koja dostiže epidemijske razmere (1). Adipociti, koji se nalaze u široko rasprostranjenom masnom tkivu u organizmu, adaptirani su da efikasno skladište energiju u obliku triglicerida i, u slučaju potrebe, putem endokrine i neuralne kontrole oslobode uskladištenu energiju u vidu slobodnih masnih kiselina, koje su potrebne za neko drugo mesto u organizmu. Ovaj mehanizam omogućava ljudima da prežive gladovanje i do nekoliko meseci. Kod obimnog unosa hrane, sedentarnog načina života i pod uticajem nekih genetskih faktora, količina adipoznog masnog tkiva se, međutim, povećava, što može da ima posledice po zdravlje.

Gojaznost se definiše kao prekomerno nakupljanje masnog tkiva. Kao koristan parametar može se koristiti indeks telesne mase (engl. Body mass index, BMI), koji predstavlja količnik težine i kvadrirane visine u metrima $\left(\mathrm{kg} / \mathrm{m}^{2}\right)$. Ukoliko je indeks telesne mase veći od $30 \mathrm{~kg} / \mathrm{m}^{2}$, ukazuje na prisutnu gojaznost. Osobe čiji je indeks telesne mase $40 \mathrm{~kg} / \mathrm{m}^{2}$ ili iznad, označavaju se kao ekstremno gojazne.

Gojaznost može da dovede do mnogih komplikacija, kao što su insulinska rezistencija, dijabetes, hiperten- zija, hiperlipidemija, hirzuitizam kod žena i mnoge druge. Iako se adipociti smatraju skladištem masti i energije, oni funkcionišu i kao endokrine ćelije koje luče mnogobrojne bioaktivne peptide - adipokine, kao što su leptin, koji reguliše energetski balans; citokini, na primer faktor nekroze tumora (engl. Tumor necrosis factor, TNF) i interleukin 6 (IL-6); faktori komplementa, npr. faktor D, poznat kao adipsin; i angiotenzinogen, koji učestvuje u regulisanju krvnog pritiska. Kod gojaznosti je smanjena koncentracija adiponektina, koji luče adipociti. On povećava insulinsku senzitivnost i lipidnu oksidaciju, a ima i protektivnu vaskularnu ulogu. Kod gojaznih osoba je, s druge strane, povećana koncentracija rezistina, koji utiče na insulinsku rezistenciju. Svi ovi, kao i mnogi drugi faktori koji se tek otkrivaju, igraju važnu ulogu u fiziologiji lipidne homeostaze, insulinske senzitivnosti, kontrole krvnog pritiska i stanja krvnih sudova i u velikom stepenu doprinose poremećajima povezanim sa gojaznošću (2).

Od značaja je i distribucija masnog tkiva u različitim anatomskim odeljcima. Visceralno masno tkivo je lokalizovano oko unutrašnjih organa i hormonski je i metabolički aktivno. Smatra se da intraabdominalno visceralno masno tkivo ima veći značaj u regulaciji glikolipidne homeostaze od supkutanog masnog tkiva, lokalizovanog $\mathrm{u}$ predelu gluteusa i donjih ekstremiteta $(2,3)$.

Ultrasonografija je pogodna vizualizaciona meto- 
Jovanović et al. Testing of correlation between amounts of visceral and subcutaneous abdominal adipose tissue in obese people measured by ultrasound and biochemical indicators of glycolipid status. MedPodml 2017, 68(2):26-32

da za merenje količine supkutanog i visceralnog masnog tkiva (4-7). Iako se kompjuterizovana tomografija (CT) i magnetna rezonanca (MR) smatraju "zlatnim standardom" u proceni količine supkutanog i visceralnog abdominalnog masnog tkiva (5), kod izrazito gojaznih pacijenata često nije moguća njihova primena zbog tehničkih karakteristika CT ili MR aparata, koji imaju ograničenu nosivost stola na kome pacijent leži, najčešće od 130 do $160 \mathrm{~kg}$, u zavisnosti od tipa aparata. Primena CT, osim toga, uslovljava izlaganje štetnom jonizujućem zračenju, a MR je skupa i još uvek ograničeno dostupna radiološka metoda. Ovakva ograničenja se ne odnose na ultrasonografiju, koja je najšire dostupna, najjeftinija, neškodljiva za pacijente i, kao takva, najpogodnija vizualizaciona metoda za procenu količine različitih kompartmana abdominalnog masnog tkiva upravo za ovu grupu pacijenata $(4,6,7)$.

Važnu ulogu u praćenju gojaznosti imaju i biohemijski pokazatelji glikolipidnog statusa, u koje spadaju serumske koncentracije glukoze, holesterola, triglicerida, insulina i glikoziliranog hemoglobina (HbA1c), kao i indeks procene modela homeostaze (engl. Homeostasis model assessment, HOMA), koji je pokazatelj insulinske rezistencije $($ HOMA IR $=$ glikemija $(\mathrm{mmol} / \mathrm{l}) \mathrm{x}$ insulinemija $(\mathrm{mU} / \mathrm{l}) / 22,5)(2)$.

Cilj ovog rada je ispitivanje povezanosti količine visceralnog i supkutanog abdominalnog masnog tkiva kod gojaznih osoba, merenih ultrazvukom, i biohemijskih pokazatelja glikolipidnog statusa.

\section{Materijal i Metode}

Retrospektivnom studijom je obuhvaćeno 183 gojaznih pacijenata (131 žena i 52 muškarca). Prosečna starost pacijenata je bila $42,6 \pm 12,2$ godina. Najmlađi pacijent je imao 18, a najstariji 71 godinu. Pacijentima je rađeno ultrasonografsko merenje supkutanog i visceralnog masnog tkiva abdomena. Merenja su vršena u periodu od juna 2011. do decembra 2015, na Odseku digestivne radiologije (Klinika za digestivne bolesti) Centra za radiologiju i magnetnu rezonancu Kliničkog centra Srbije. Pored ultrasonografskih merenja, prethodno su rađena i antropometrijska merenja: visina, telesna težina, BMI, obim struka (OS) i obim kukova (OK), kao i biohemijske analize, kojima su merene serumske koncentracije glukoze, HbA1c, triglicerida i ukupnog holesterola.

Ultrazvučna merenja prečnika abdominalnog masnog tkiva vršena su konveksnom ultrazvučnom sondom frekvencije 3-5 $\mathrm{MHz}$ i linearnom sondom frekvencije 5-10 MHz, nakon adekvatne pripreme pacijenta (8 sati bez obroka). Analizirana su dva prečnika abdominalnog masnog tkiva (4-7): 1) prečnik visceralnog abdominalnog masnog tkiva (dVAMT), koji odgovara rastojanju između linee albe, odnosno zadnje površine $\mathrm{m}$. rectus abdominisa i prednjeg zida aorte, meren oko $2 \mathrm{~cm}$ iznad nivoa pupka (u nivou struka) i 2) prečnik supkutanog abdominalnog masnog tkiva (dSCAMT), koji predstavlja rastojanje od kože do linee albe, meren na istoj visini kao i dVAMT (slika 1). Indeks dVMAT/dSCAMT predstavlja odnos (količnik) prečnika visceralnog i supkutanog masnog tkiva (dVMAT/dSCAMT).

Telesna visina, težina, OS i OK mereni su na standardan način.

Nivo glukoze se određuje enzimskom metodom pomoću glukozooksidaze. Rađeno je i merenje koncentracije HbAlc. Određeni su i nivoi ukupnog holesterola i triglicerida u serumu enzimskom metodom. Za sve ove analize krv se uzima ujutru našte, nakon 12 sati gladovanja.

Podaci dobijeni merenjem su predstavljeni srednjom vrednošću i standardnom devijacijom, kao i rangom od minimalne do maksimalne vrednosti. Od statističkih testova za obradu podataka korišćene su metode deskriptivne statistike i Pirsonov koeficijent linearne korelacije. Podaci su se smatrali statistički značajnim sa nivoom značajnosti $\mathrm{p}<0,05$. Statistička analiza je urađena uz pomoć statističkog programa SPSS 17.0.

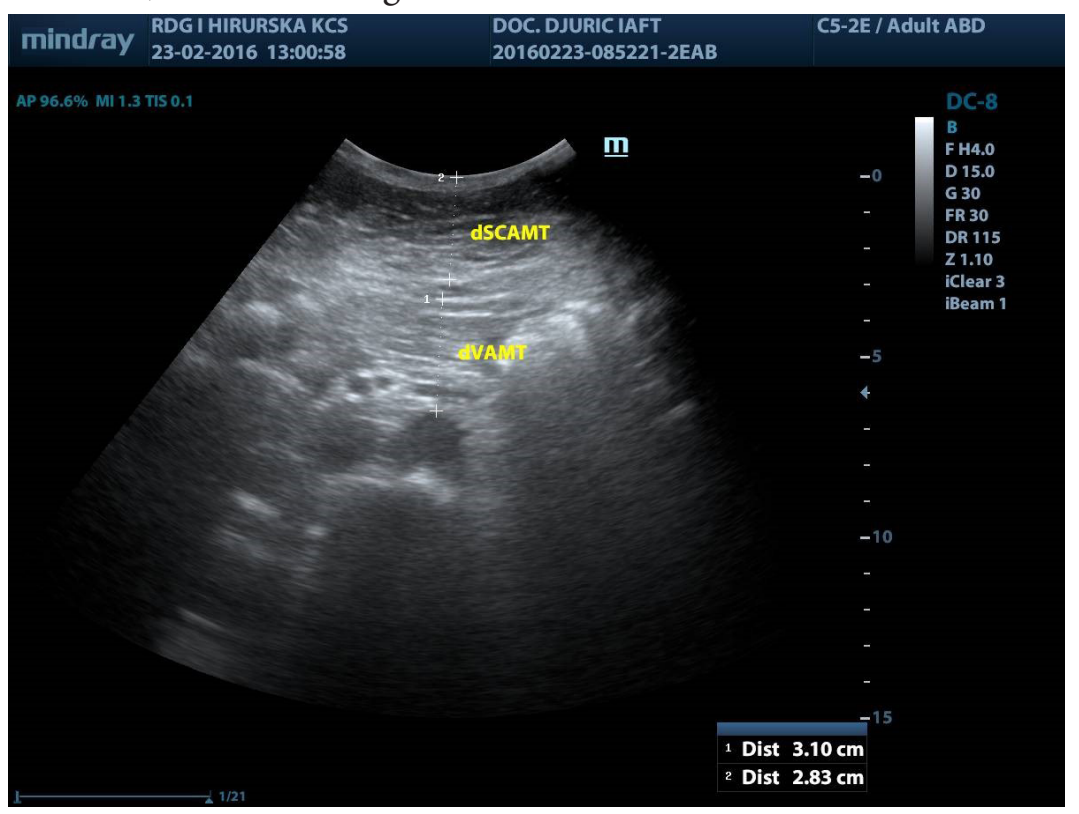

Slika 1. Ultrazvučno mereni prečnici visceralnog (dVAMT) i supkutanog (dSCAMT) abdominalnog masnog tkiva (poprečni presek na oko $2 \mathrm{~cm}$ iznad pupka). 
Jovanović et al. Testing of correlation between amounts of visceral and subcutaneous abdominal adipose tissue in obese people measured by ultrasound and biochemical indicators of glycolipid status. MedPodml 2017, 68(2):26-32

\section{Rezultati}

Od antropometrijskih parametara, dVAMT je najviše korelirao sa obimom struka, dSCAMT sa obimom kukova, a indeks dVAMT/dSCAMT sa indeksom OS/OK.

Korelacije između ultrazvučno izmerenih prečnika abdominalnog masnog tkiva dVAMT i dSCAMT, kao i dVAMT/dSCAMT indeksa i biohemijskih indikatora glikolipidnog statusa (serumske koncentracije glukoze, HbAlc, triglicerida i ukupnog holesterola), prikazane su u tabeli 5.

Utvrdili smo statistički visokoznačajnu pozitivnu korelaciju između prečnika abdominalnog visceralnog

Tabela 1. Antropometrijski parametri ispitanika masnog tkiva i svih analiziranih biohemijskih parametara glikolipidnog stausa, osim ukupnog holesterola, od kojih je najveća korelacija bila sa koncentracijom triglicerida. Statistički veoma značajna, mada slabija u odnosu na dVAMT, negativna (inverzna) korelacija utvrđena je između debljine supkutanog abdominalnog masnog tkiva i koncentracije glukoze, HbAlc i triglicerida, dok sa ukupnim holestorolom nije nađena statistički značajna korelacija. Indeks dVAMT/dSCAMT je više od dVAMT i dSCAMT pojedinačno pozitivno korelirao sa serumskom koncentracijom glukoze, HbAlc i triglicerida, dok sa koncentracijom ukupnog holesterola nije utvrđena statistički značajna korelacija.

\begin{tabular}{|l|l|l|l|l|l|l|}
\hline & Starost (godine) & Težina $(\mathrm{kg})$ & BMI $\left(\mathrm{kg} / \mathrm{m}^{2}\right)$ & OS $(\mathrm{cm})$ & OK $(\mathrm{cm})$ & OS/OK \\
\hline $\mathrm{x} \pm$ SD & $42,6 \pm 12,2$ & $123,4 \pm 26,7$ & $43,5 \pm 7,6$ & $125,5 \pm 15,4$ & $133,2 \pm 12,9$ & $0,94 \pm 0,08$ \\
\hline Rang (min-max) & $18-71$ & $77-248$ & $29,2-75,0$ & $88-176$ & $105-170$ & $0,72-1,14$ \\
\hline $\mathrm{n}$ & 183 & 183 & 183 & 180 & 170 & 170 \\
\hline
\end{tabular}

OS - obim struka; OK - obim kukova, $\mathrm{x}$ - aritmetička sredina; SD-standardna devijacija; $\mathrm{n}$ - broj ispitanika

Tabela 2. Prečnici visceralnog (dVAMT) i supkutanog (dSCAMT) masnog tkiva izmereni ultrazvukom

\begin{tabular}{|c|c|c|c|}
\hline & dVAMT $(\mathrm{mm})$ & dSCAMT $(\mathrm{mm})$ & dVAMT/dSCAMT indeks \\
\hline $\mathrm{x} \pm \mathrm{SD}$ & $89,5 \pm 33,5$ & $48,1 \pm 16,2$ & $2,23 \pm 1,77$ \\
\hline Rang (min-max) & $26-181$ & $13-112$ & $0,38-12,93$ \\
\hline $\mathrm{n}$ & 183 & 171 & 171 \\
\hline
\end{tabular}

Korelacije između antropometrijskih parametara (telesna težina, BMI, OS, OK i OS/OK indeksa) i biohemijskih indikatora glikolipidnog statusa (serumske koncentracije glukoze, HbA1c, triglicerida i ukupnog holesterola) prikazane su u tabeli $\mathbf{6}$.

Od standardnih antropometrijskih parametara pojedinačno (telesna težina, BMI, OS i OK), obim struka je statistički veoma značajno, mada slabije nego dVAMT i dAVMT/dSCAMT indeks, korelirao sa koncentracijom svih biohemijskih parametara glikolipidnog statusa, osim ukupnog holesterola, dok između telesne težine, kao i BMI, nije nađena statistički značajna korelacija sa analiziranim biohemijskim parametrima glikolipidnog statusa. Značajna korelacija je utTabela 3. Vrednosti biohemijskih parametara glikolipidnog statusa

\begin{tabular}{|c|c|c|c|c|}
\hline & $\begin{array}{c}\text { Glukoza } \\
(\mathrm{mmol} / \mathrm{l})\end{array}$ & $\begin{array}{c}\text { HbA1c } \\
(\%)\end{array}$ & $\begin{array}{c}\text { Trigliceridi } \\
(\mathrm{mmol} / \mathrm{l})\end{array}$ & $\begin{array}{c}\text { Holesterol } \\
(\mathrm{mmol} / \mathrm{l})\end{array}$ \\
\hline $\mathrm{x} \pm \mathrm{SD}$ & $5,46 \pm 2,4$ & $6,02 \pm 1,39$ & $2,11 \pm 1,19$ & $\begin{array}{c}5,38 \pm \\
1,04\end{array}$ \\
\hline $\begin{array}{c}\text { Rang } \\
(\mathrm{min}-\mathrm{max})\end{array}$ & $2,2-6,9$ & $3,9-11,9$ & $0,39-6,43$ & $3,1-7,85$ \\
\hline $\mathrm{n}$ & 181 & 171 & 165 & 168 \\
\hline $\begin{array}{c}\text { Referentne } \\
\text { vrednosti }\end{array}$ & $3,3-6,5$ & $4,5-6,3$ & $<2$ & $<5,2$ \\
\hline
\end{tabular}
vrđena između indeksa OS/OK i koncentracije glukoze, HbAlc i triglicerida, dok sa koncentracijom ukupnog holesterola nije nađena statistički značajna povezanost.

Tabela 4. Korelacija prečnika dVAMT i dSCAMT i antropometrijskih parametara ispitanika

\begin{tabular}{|c|c|c|c|c|c|c|}
\hline & \multirow{4}{*}{$\begin{array}{l}\mathbf{r} \\
\mathbf{p} \\
\mathrm{n}\end{array}$} & Težina & BMI & OS & $\mathrm{OK}$ & $\mathrm{OS} / \mathrm{OK}$ \\
\hline dVAMT & & $\begin{array}{l}0,519^{* *} \\
0 \\
183\end{array}$ & $\begin{array}{l}0,520^{* *} \\
0 \\
183\end{array}$ & $\begin{array}{l}0,659^{* *} \\
0 \\
180\end{array}$ & $\begin{array}{l}0,323^{* *} \\
0 \\
170\end{array}$ & $\begin{array}{l}0,597^{\star *} \\
0 \\
170\end{array}$ \\
\hline dSCAMT & & $\begin{array}{l}0,446^{* *} \\
0 \\
171\end{array}$ & $\begin{array}{l}0,353^{* *} \\
0 \\
171 \\
\end{array}$ & $\begin{array}{l}0,243^{* *} \\
0 \\
169\end{array}$ & $\begin{array}{l}0,459^{* *} \\
0 \\
159\end{array}$ & $\begin{array}{l}-0,123 \\
0,123 \\
159 \\
\end{array}$ \\
\hline dVAMT/dSCAMT indeks & & $\begin{array}{l}0,063 \\
0,413 \\
171\end{array}$ & $\begin{array}{l}0,083 \\
0,282 \\
171\end{array}$ & $\begin{array}{l}0,246^{\star *} \\
0,001 \\
169\end{array}$ & $\begin{array}{l}-0,102 \\
0,200 \\
159\end{array}$ & $\begin{array}{l}0,495^{\star *} \\
0 \\
159\end{array}$ \\
\hline
\end{tabular}

$\mathrm{r}$ - Pirsonov koeficijent linearne korelacije; $\mathrm{p}$ - nivo statističke značajnosti $\left({ }^{*} \mathrm{p}<0,05 ;{ }^{* *} \mathrm{p}<0,01\right) ; \mathrm{n}$ - broj pacijenata 
Jovanović et al. Testing of correlation between amounts of visceral and subcutaneous abdominal adipose tissue in obese people measured by ultrasound and biochemical indicators of glycolipid status. MedPodml 2017, 68(2):26-32

Tabela 5. Korelacija ultrazvučno izmerenih prečnika dVAMT i dSCAMT i biohemijskih parametara glikolipidnog statusa

\begin{tabular}{|c|c|c|c|c|c|}
\hline & \multirow{4}{*}{$\begin{array}{l}\mathbf{r} \\
\mathbf{p} \\
\mathrm{n}\end{array}$} & Glukoza & HbAlc & Trigliceridi & Holesterol \\
\hline dVAMT & & $\begin{array}{l}0,372^{\star *} \\
0 \\
181\end{array}$ & $\begin{array}{l}0,410^{* *} \\
0 \\
171\end{array}$ & $\begin{array}{l}0,409^{* *} \\
0 \\
165\end{array}$ & $\begin{array}{l}0,109 \\
0,158 \\
168\end{array}$ \\
\hline dSCAMT & & $\begin{array}{l}-0,364^{* *} \\
0 \\
169\end{array}$ & $\begin{array}{l}-0,230^{* *} \\
0,003 \\
160\end{array}$ & $\begin{array}{l}-0,215^{\star *} \\
0,008 \\
154\end{array}$ & $\begin{array}{l}-0,132 \\
0,100 \\
157 \\
\end{array}$ \\
\hline $\begin{array}{l}\text { dVAMT/dSCAMT } \\
\text { indeks }\end{array}$ & & $\begin{array}{l}0,534^{\star *} \\
0 \\
169\end{array}$ & $\begin{array}{l}0,456^{\star *} \\
0 \\
160\end{array}$ & $\begin{array}{l}0,443^{\star *} \\
0 \\
154\end{array}$ & $\begin{array}{l}0,132 \\
0,100 \\
157\end{array}$ \\
\hline
\end{tabular}

$\mathrm{r}$ - Pirsonov koeficijent linearne korelacije; $\mathrm{p}$ - nivo statističke značajnosti $\left({ }^{\star} \mathrm{p}<0,05 ;{ }^{* *} \mathrm{p}<0,01\right)$; $\mathrm{n}$ - broj pacijenata

Tabela 6. Korelacija antropometrijskih parametara i biohemijskih parametara glikolipidnog statusa

\begin{tabular}{|c|c|c|c|c|c|}
\hline & \multirow{6}{*}{$\begin{array}{l}\mathbf{r} \\
\mathbf{p} \\
\mathbf{n}\end{array}$} & Glukoza & HbAlc & Trigliceridi & Holesterol \\
\hline Težina & & $\begin{array}{l}0,064 \\
0,390 \\
181\end{array}$ & $\begin{array}{l}0,141 \\
0,065 \\
171\end{array}$ & $\begin{array}{l}0,028 \\
0,725 \\
165\end{array}$ & $\begin{array}{l}-0,089 \\
0,252 \\
168\end{array}$ \\
\hline BMI & & $\begin{array}{l}0,053 \\
0,481 \\
181\end{array}$ & $\begin{array}{l}0,135 \\
0,079 \\
171\end{array}$ & $\begin{array}{l}0,004 \\
0,964 \\
165\end{array}$ & $\begin{array}{l}-0,011 \\
0,889 \\
168\end{array}$ \\
\hline OS & & $\begin{array}{l}0,234^{\star *} \\
0,002 \\
178\end{array}$ & $\begin{array}{l}0,283^{\star *} \\
0 \\
168\end{array}$ & $\begin{array}{l}0,197^{\star} \\
0,012 \\
162 \\
\end{array}$ & $\begin{array}{l}-0,005 \\
0,947 \\
165\end{array}$ \\
\hline $\mathrm{OK}$ & & $\begin{array}{l}-0,004 \\
0,964 \\
168\end{array}$ & $\begin{array}{l}0,054 \\
0,499 \\
152\end{array}$ & $\begin{array}{l}-0,111 \\
0,173 \\
152\end{array}$ & $\begin{array}{l}0,014 \\
0,867 \\
155\end{array}$ \\
\hline OS/OK & & $\begin{array}{l}0,361^{* *} \\
0 \\
168\end{array}$ & $\begin{array}{l}0,362^{\star *} \\
0 \\
152\end{array}$ & $\begin{array}{l}0,410^{* *} \\
0 \\
152\end{array}$ & $\begin{array}{l}-0,031 \\
0,704 \\
155\end{array}$ \\
\hline
\end{tabular}

$\mathrm{r}$ - Pirsonov koeficijent linearne korelacije; $\mathrm{p}$ - nivo statističke značajnosti $\left({ }^{\star} \mathrm{p}<0,05 ;{ }^{*} \mathrm{p}<0,01\right)$; $\mathrm{n}$ - broj pacijenata

\section{Diskusija}

$\mathrm{U}$ radu smo ispitivali da li postoji povezanost između ultrasonografski izmerene debljine (prečnika) visceralnog i supkutanog abdominalnog masnog tkiva i biohemijskih pokazatelja glikolipidnog statusa, odnosno serumske koncentracije glukoze, HbA1c, triglicerida i ukupnog holesterola, u populaciji odraslih gojaznih osoba oba pola $\left(\mathrm{BMI}>30 \mathrm{~kg} / \mathrm{m}^{2}\right)$. Pored toga, ispitivali smo i povezanost osnovnih antropometrijskih parametara $u$ koje smo uvrstili težinu, indeks telesne mase, obim struka i obim kukova i pomenutih biohemijskih parametara glikolipidnog statusa.

Merenje prečnika abdominalnog masnog tkiva ultrazvukom je brzo i lako izvodljivo, ali se u literaturi navodi da su reproduktivnost i ponavljanja lošiji u odnosu na "cross-sectional" metode vizualizacije: CT i MR (4, 5). Objavljeni podaci da su prečnici mereni ultrazvukom od zadnje ivice $\mathrm{m}$. rectus abdominisa do aorte dobro korelirali sa istim prečnicima merenim CT-om. pokazali su, međutim, da je ultrazvuk pouzdana vizualizaciona metoda za merenje, tj. za procenu količine dva različita depoa intraabdominalnog masnog tkiva, visceralnog i supkuta- nog $(5,6)$. Ultrazvuk je istovremeno najpogodnija vizualizaciona metoda za merenje dva različita kompartmenta abdominalnog masnog tkiva, visceralnog i supkutanog, $\mathrm{u}$ gojaznih osoba.

U većini objavljenih studija ispitivanaje povezanost serumske koncentracije biohemijskih pokazatelja glikolipidnog statusa, koji istovremeno predstavljaju biohemijske markere metaboličkog sindroma, sa antropometrijskim parametrima, u prvom redu BMI i obimom struka, ili, u manjem broj uradova, sa količinom visceralnog, odnosno supkutanog abdominalnog masnog tkiva, merenih CT-om (3, 8-13). Park i sar. su u svojoj studiji pokazali da postoji povezanost izmedu vrednosti triglicerida i antropometrijskih parametara, pre svega indeksa telesne mase i obima struka, kao i da postoji povezanost sa količinom visceralne masti, ali ne i sa količinom supkutane masti, što se slaže sa našim rezultatima (8). Ribeiro-Filho i sar., kao i Pasko (Pascot) i sar. u svojim studijama su pokazali da povećanje količine visceralnog masnog tkiva korelira sa povišenim vrednostima triglicerida i insulinskom rezistencijom (9, 10). Nekoliko studija, među kojima je i studija Brenera (Brenner) i sar. pokazale su pozitivnu korelaciju između vrednosti triglicerida i obima struka (11-13). U našem radu smo utvrdili statistički značajnu pozitivnu korelaciju 
Jovanović et al. Testing of correlation between amounts of visceral and subcutaneous abdominal adipose tissue in obese people measured by ultrasound and biochemical indicators of glycolipid status. MedPodml 2017, 68(2):26-32

između debljine visceralnog abdominalnog masnog tkiva, indeksa prečnika visceralnog i supkutanog abdominalnog masnog tkiva i serumske koncentracije glukoze i HbAlc, iako su prosečne vrednosti ovih biohemijskih parametara u našoj ispitivanoj populaciji odraslih gojaznih osoba bile u referentnim granicama. Seibert i sar. su pretpostavili da pankreas, u određenom vremenskom periodu, može adekvatno da kompenzuje perifernu insulinsku rezistenciju tako što će povećavati sintezu insulina dokle god beta ćelije poseduju kapacitet za proizvodnju ovog hormona. Nakon njihovog iscrpljenja i nedovoljne sekrecije posledično će se javiti hiperglikemija (14). U ovoj studiji je pokazano i da kod gojaznih osoba postoje povišene vrednosti insulina i HOMA indeksa insulinske rezistencije, što ide u prilog prethodno objašnjenom (14). Slične rezultate pokazale su i još neke studije $(15,16)$. Sen i sar. su pokazali veću prevalenciju metaboličkog sindroma i insulinske rezistencije kod gojaznih adolescenata (15), dok su Santos i sar. u svojoj studiji dobili povišene vrednosti glukoze i HOMA indeksa $\mathrm{u}$ istoj populaciji i time ukazali na povezanost između insulinske rezistencije i količine telesne masnoće (16). Korelacija između povećanja visceralne masnoće i vrednosti glukoze može se objasniti pojavom insulinske rezistencije, zbog čega se pojačano luči insulin iz pankreasa, kao kompenzatorni mehanizam, dok se u jednom trenutku, kada to više nije dovoljno, ne javi i hiperglikemija. U prilog ovome ide i pretpostavka, koju su u svojoj studiji izložili Seibert i sar. (14). Interesantno je navesti i obrnutu, inverznu korelaciju između debljine supkutanog abdominalnog masnog tkiva i vrednosti glukoze, HbAlc i triglicerida, koju smo dobili u ovom radu, što se slaže se sa rezultatima rada Chen i sar. (17). Ovakvi nalazi bi mogli da idu u prilog hipotezi da supkutano masno tkivo na neki način regulatorno, tj. zaštitno deluje na glikolipidni status, moguće predstavljajući ravnotežni rezervni depo masnog tkiva koji sprečava ekscesivno nagomilavanje visceralnog masnog tkiva.

U našoj studiji smo pokazali da postoji povezanost između određenih antropometrijskih parametara i vrednosti prečnika dva kompartmenta abdominalnog masnog tkiva, tako da obim struka najbolje odražava količinu visceralnog, obim kukova supkutanog, a indeks OS/OK odnos količine visceralnog i supkutanog abdominalnog masnog tkiva. Potvrdili smo i postojanje povezanosti između količine visceralnog abdominalnog masnog tkiva

\section{Literatura}

1. Rang H, Dale M, Ritter J, Moore P. Farmakologija. Beograd: Data status; 2005.

2. Fauci A, Kasper D, Longo D, Loscalzo J, Braunwald E, Hauser S, et al. Harrison's principles of internal medicine 17th edition. New York: Mc Graw Hill Medical; 2008.

3. Fox CS, Massaro JM, Hoffman U, Pou KM, Maurovich-Horvat $\mathrm{P}, \mathrm{Liu} \mathrm{CY}$ et al. Abdominal visceral and subcutaneous adipose tissue compartments: association with metabolis risk factors in the Framingham heart study. Circulation. 2007;116(1):39-48.

4. Pontiroli AE, Pizzocri P, Giacomelli M, Marchi M, Vedani u gojaznih osoba i svih pokazatelja glikolipidnog statusa, izuzev ukupnog holesterola, što se slaže sa rezultatima u prethodno navedenim radovima (16). Našli smo, međutim, da indeks dVAMT/dSCAMT merenih ultrazvukom $\mathrm{u}$ visini struka najviše korelira sa biohemijskim parametrima glikolipidnog statusa, osim totalnog holesterola, te bi ovaj indeks mogao da predstavlja najbolji surogat marker za procenu rizika od zdravstvenih komplikacija kod gojaznih osoba. U daljim istraživanjima potrebno je utvrditi granične vrednosti ovog indeksa u odnosu na pol i godine starosti, koje bi predstavljale indikator visokog rizika za najčešća oboljenja povezana sa gojaznošću.

Dva glavna nedostatka prikazane studije su: izostanak stratifikacije ispitivane populacije prema polu i starosti, kao i to što je među biohemijskim parametrima bila zastupljena samo koncentracija ukupnog holesterola, a ne i koncentracije njegovih frakcija: lipoproteina velike (LDL), odnosno male gustine (HDL), zbog čega nije bilo moguće analizirati povezanost između ultrazvučno procenjene količine visceralnog i supkutanog masnog tkiva i koncentracije LDL holesterola, kao i indeksa serumske koncentracije triglicerida i HDL holesterola, koji predstavljaju biohemijske markere metaboličkog sindroma.

\section{Zaključak}

U radu je pokazano da vrednosti prečnika visceralnog abdominalnog masnog tkiva, kao i odnosa prečnika visceralnog i supkutanog masnog tkiva, merenih ultrazvukom u odraslih gojaznih osoba, dobro koreliraju sa biohemijskim parametrima glikolipidnog statusa, osim sa koncentracijom ukupnog holesterola. Određeni antropometrijski parametri (OS i indeks OS/OK) pokazuju slabiju povezanost sa istim biohemijskim parametrima glikolipidnog statusa. U tom smislu, možemo da zaključimo da metoda ultrasonografskog merenja prečnika visceralnog i supkutanog abdominalnog masnog tkiva kod odraslih gojaznih osoba, kao brza, neškodljiva i jednostavno primenljiva metoda u svakodnevnoj kliničkoj praksi, može da bude od koristi u kliničkoj obradi ove populacije radi pouzdanije individualne procene stepena rizika od najčešćih komplikacija gojaznosti kao što su dijabetes, hiperlipidemija i metabolički sindrom.

P, Cucchi Eet al. Ultrasound measurement of visceral and subcutaneous fat in morbidly obese patients before and after laparoscopic adjustable gastric banding: comparison with computerized tomography and with anthropometric measurements. Obes surg. 2002;12(5):648-51.

5. Hirooka M, Kumagi T, Kurose K, Nakanishi S, Michitaka K, Matsuura B et al. A technique for the measurement of visceral fat by ultrasonography: comparison of measurement by ultrasonography and computed tomography. Intern med. 2005;44(8):794-9.

6. Vlachos IS, Hatzioannou A, Perelas A, Perrea DN. Sono- 
Jovanović et al. Testing of correlation between amounts of visceral and subcutaneous abdominal adipose tissue in obese people measured by ultrasound and biochemical indicators of glycolipid status. MedPodml 2017, 68(2):26-32

graphic assessment of regional adiposity. Am J Roendgenol. 2007;189(6):1545-53.

7. Stolk RP, Meijer R, Mali WP, Grobbee DE, van der Graaf Y. Secondary Manifestations of Arterial Disease Study Group. Ultrasound measurement of intraabdominal fat estimate the metabolic syndrome better than do measurements of waist circumference. Am J Clin Nutr. 2003;77(4):857-60.

8. Park HR, Shin SR, Han AL, Jeong YJ. The Correlation between the triglyceride to high density lipoprotein cholesterol ratio and computed tomography- measured visceral fat and cardiovascular disease risk factors in local adult male subjects. Korean J Fam Med. 2015;36(6):335-40.

9. Ribeiro-Filho FF, Faria AN, Kohlmann NE, Zanella MT, Ferreira SR. Two-hour insulin determination improves the ability of abdominal fat mea $\neg$ surement to identify risk for the metabolic syndrome. Diabetes Care. 2003;26(6):172530.

10. Pascot A, Despres JP, Lemieux I, Bergeron J, Nadeau A, Prud'homme D et al. Contribution of visceral obesity to the deterioration of the meta $\neg$ bolic risk profile in men with impaired glucose tolerance. Diabetologia. 2000;43(9):1126-35.

11. Brenner DR, Tepylo K, Eny KM, Cahill LE, El-Sohemy A. Comparison of body mass index and waist circumference as predictors of cardio $\neg$ metabolic health in a population of young Canadian adults. Diabetol Metab Syndr.
2010;2(1):28.

12. Ozkaya I, Bavunoglu I, Tunckale A. Body mass index and waist circum $\neg$ ference affect lipid parameters negatively in Turkish women. Am J Pub $\neg$ lic Health Res. 2014;2:226-31.

13. Kim JS, Kang HT, Shim JY, Lee HR. The association between the triglyc $\neg$ eride to high-density lipoprotein cholesterol ratio with insulin resis $\neg$ tance (HOMA-IR) in the general Korean population: based on the $\mathrm{Na} \neg$ tional Health and Nutrition Examination Survey in 2007-2009. Diabe $\neg$ tes Res Clin Pract. 2012;97(1):132-8.

14. Seibert H, Pereira AM, Ajzen SA, Nogueira PC. Abdominal circumference measurement by ultrasound does not enhance estimating the association of visceral fat with cardiovascular risk. Nutrition. 2013;29(2):393-8.

15. Sen Y, Kandemir N, Alikasifoglu A, Gonc N, Ozon. Prevalence and risk factors of metabolic syndrome in obese children and adolescents: the role of the severity of obesity. Eur J Pediatr. 2008;167(10):1183-9.

16. Santos LC, Cintra Ide P, Fisberg M, Martini LA. Body trunk fat and insulin resistance in post-pubertal obese adolescents. Sao Paulo Med J. 2008;126(2):82-6.

17. Chen K, Xie Y, Hu P, Zhao S, Mo Z. Multiple symmetric lipomatosis: substantial subcutaneous adipose tissue accumulation did not induce glucose and lipid metabolism dysfunction. Ann Nutr Metab. 2010; 57(1):68-73. 